\title{
CONSUMER RISK PERCEPTIONS ON THE PURCHASES OF SHOPPING GOODS- A FIELD STUDY IN ANKARA, TURKEY
}

\author{
NURI CALIK, N. FIGEN ERSOY
}

\begin{abstract}
:
This study intends to find out the consumer risk perception in the purchases of shopping goods.. A survey on 880 respondents who are selected via stratified sampling of which 863 are found eligible to be analyzed. The respondents are required to answer 50 questions of which five are related to demographic characteristics of these respondents. The rest 45 are statements which are designed to reflect the innovativeness and risk perception of the consumers which are two controversial issues... The study consists of five parts. The first part is an introduction where the scope and the purpose of the study are concisely stated. The second part relates to the theoretical background of the subject matter and the prior researches carried out so far. The third part deals with research methodology, basic premises and hypotheses attached to these premises. Research model and analyses take place in this section. Theoretical framework is built and a variable name is assigned to each of the question asked or proposition forwarded to the respondents of this survey. 45 statements or propositions given to the respondents are placed on a five-point Likert scale. The remaining five questions about demographic traits as age, gender, occupation, educational level and monthly income are placed either on a nominal or ratio scale with respect to the nature of the trait. Five research hypotheses are formulated in this section. The fourth part mainly deals with the results of the hypothesis tests and a factor analysis is applied to the data on hand. Here exploratory factor analysis reduces 45 variables to eight basic components as "Online shopping risks, technology readiness, risk avoidance, physical risk perception, consumer innovativeness, functional risk perception, information seeking behavior, and social risk perception. Cronbach's Alpha for scale reliability is (alfa $=0.731$ ) and the sample adequacy ratio (KMO) is 0.835 . In addition non-parametric bivariate analysis in terms of Chi-Square is applied to test the hypotheses formulated in this respect. The fifth part is the conclusion where findings of this survey are listed.
\end{abstract}

\section{Keywords:}

Consumer innovativeness, information seeking behavior, risk perception and risk avoidance, technology-proneness, functional and physical risks.

JEL Classification: M31

\section{Authors:}

NURI CALIK , Turgut Özal University Faculty of Economics and Administrative Sciences Department of Business Administration, Turkey, Email: drnuricalik@gmail.com

N. FIGEN ERSOY, Anadolu University Faculty of Economics and Administrative Sciences Department of Business Administration, Turkey, Email: nfersoy@anadolu.edu.tr

\section{Citation:}


NURI CALIK , N. FIGEN ERSOY (2016). CONSUMER RISK PERCEPTIONS ON THE PURCHASES OF SHOPPING GOODS- A FIELD STUDY IN ANKARA, TURKEY. International Journal of Social Sciences, Vol. $\mathrm{V}(4)$, pp. 19-43., 10.20472/SS.2016.5.4.002 


\section{Introduction}

Innovation, risk perception, information seeking and online shopping are some of the terms which found a wide acceptance by the consumer in the last three or four decades, especially when these terms refer to specialty items and high-technology products. The aim of this study is to examine the several aspects of the consumer behavior that they display during the time of purchase or decision to buy period. Consumers' familiarity with a sophisticated brand is often correlated negatively with their perceptions of functional, financial, physical, social, and psychological risks. On the other hand consumers' self-confidence and trust is positively correlated with the value or quality of that brand. This paper tries to find out the pros and cons of the consumer behavior in the realm of perceived risks.

\section{Literature Review and Prior Research}

There are more general marketing facts that everyone knows: as many as $90 \%$ of new products that are introduced into market each year fail. So, this factor leads to marketers to deal with risk minimization. Recent researches and articles on consumer perceptions of risk have found that consumers faced with uncertainty often view a new product as an either set of benefits or losses. (Cox, Cox\&Zimet, 2006; Cox, Cox \& Mantel, 2010; Philips \& Hallman, 2013, Schiffmann \&Kanuk, 2010). Actually at this point, it is needed to look the relationship between consumers' risk perceptions and innovativeness. Because these concepts are related with each other and assumed that consumer innovativeness is negatively correlated with consumer risk perceptions.

\section{Product and Consumer Innovativeness}

What is innovation? Answer of this question is related to "new". A second question emerges in here. How new is new? Or, in terms of this study's focus, how innovate is innovation? According to Lowe and Alpert (2015), a better understanding of consumer perception of innovativeness may help to explain forecast consumers' unanticipated and often negative reactions new products that firms had expected would be successful. Researchers have studied consumer acceptance of innovations in relation to product innovativeness (Lowe \& Alpert, 2015). In these studies, products may be new or radically new depending on whether they are marketing innovations or technology innovations and whether they are macro or micro level innovations (Garcia \&Calantone, 2002).

In the literature, there are some definitions and terms on product newness. Product newness is the extent to which the new product is compatible with the experiences and consumption patterns of potential customers to Gima (1995). According to the definitions of Moorman (1995) and Moorman \&Miner (1997) product newness also 
measures creativity at the product. However, Olshavsky and Spreng (1996) measure product newness as perceived innovativeness. Also, Alexander et al. (2008) focused perceived newness to explain product newness. (Lowe\& Alpert, 2015)

Product innovativeness is related to (Danneels and Kleinschmidt, 2001):

- key innovation characteristics

- adoption risk

- The degree of change from established behavior patterns.

Also, both of consumer and product innovativeness are related to perceived innovativeness. In this way, a main approach has been to define perceived innovativeness by how new product is (Lowe \& Alpert, 2015).. According to Cotte \&Wood (2004) and Roehrich (2004), consumer innovativeness refers to the tendency to willingly embrace change and try new things and buy new products more often and more quickly than other people. In this point although this concept differs from early adopters, several researches have indicated have indicated that innovativeness as a discriminator of early adopters from late adopters in not entirely consistent (Hirunyawipada\&Paswan, 2006). Consumer innovativeness actually depends on personality as such it can be defined in terms of a particular combination of traits.

Some of consumer innovativeness studies are shown in table 1.

Consumer innovativeness falls into subgroups as follow (Hirunyawipada\&Paswan, 2006):

- Global innovativeness: The general assumptions of global innovativeness are anchored in personality inventory that determines behaviour, especially the adoption of new products. Actullay, global innovativeness is a personel trait at the highest level of separation. Although some researches have theorized global innovativeness trait as single construct, others suggest it to be multidimensional which is including sensory and cognitive traits. These dimensions of innovativeness trait underline the disparate lists of activities. (Leavitt and Walton, 1975; Ostlund, 1972; Midgley \&Dowling, 1978; Pearson, 1970; Wood \&Swait, 2002; Baumgartner \& Steenkamp, 1996; Hirunyawipada\&Paswan, 2006)

- Domain-specific innovativeness: Domain-Specific innovativeness aims to explicate the narrow facets of human behavior within a person's specific interest domain. It contains the individual's predisposition toward the product class and it refers to the inclination to acquire new products or related information. ()

- Actualized innovativeness: Actualized innovativeness is the extent to which consumers are relatively early in adopting new products than others. At this 
point, the time of adoption behaviour is a major criterion that distinguishes early adopters than late adopters. (Rogers, 2003; Midgley \&Dowling, 1978; Hirunyawipada\&Paswan, 2006)

\section{Perceptions of Risk}

Risk is a word that has many meanings. As stated above, perception of risk has found that consumers faced with uncertainty often view a new product as a either set of benefits or losses. Perceived risk is a function of the unexpected results (Fortsyhe \& Shi, 2003; Hirunyawipada\&Paswan, 2006). Perceived risk is defined as the uncertainty that consumers face when they cannot foresee the consequences of their purchase decisions. This definition highlights two relevant dimensions of perceived risk: uncertainty and consequences (Schiffmann \&Kanuk,2010).

Risk perception is always measured in different scales. Risk perception is always measures according to the following scales:

- Lindell and Hwang (2008): Individual's expectations about likelihood of personally physical and social impacts caused by hazard

- Tepstra and Lindell (2013): People's perceptions of hazard likelihood

- Slovic at al. (2001): outrace factors

- Weyman et al. (2006): institutional trust

In general, consumer faces different kind of risk. These are functional, financial, physical, social, psychological and time risk. The amount of knowledge which is people have about a technology is related to people's risk perception on technology (Zhu, Wei \& Zhao, 2016). Regarding to this, functional risk has some effects on consumer innovativeness. Namely, a number research studies support the view that consumers rely on price as an indicator of product quality, particularly in the absence of other available information. Also, well-known brand name and store information has been shown to positively influence perceptions of quality (Schiffman and Kanuk, 2010). In other words, purchasing perceived quality product implies that the consumer is employing risk-reducing strategy ( Simcock, Sudbury \& Wright, 2006). To understand consumer perceptions of risk, it should defined antecedents and consequences of risk.

\section{Research Model and Hypotheses}

This field research is conducted in May 2015 in Ankara, Turkey, the Capital of Turkey with 4.500 .000 inhabitants. A survey on 880 respondents who are selected via stratified sampling of which 863 are found eligible to be analyzed. The respondents 
are required to answer 50 questions of which five are related to demographic characteristics of these respondents. The rest 45 are statements which are designed to reflect the innovativeness and risk perception of the consumers which are two controversial issues. Seventy-five junior students taking a "Marketing Management" course are selected as pollsters and are given extra credits for collecting reliable information. 40 statements are placed on a five-point Likert scale type ranging from " $1=$ strongly disagree" to " $5=$ strongly agree." The survey also included one ordinal scale type and five nominal and interval type demographic questions.

\subsection{Variables Grouped into Components and with Parameters Assigned}

The variables used in the analyses and their explanations are as follows:

Table 1. Variables and Their Explanations

\begin{tabular}{|c|c|c|c|}
\hline Variable & Explanation & $\begin{array}{c}\text { Mea } \\
n\end{array}$ & SD \\
\hline & A - PERCEIVED RISKS IN ONLINE SHOPPING & & \\
\hline JUDGEQUAL & $\begin{array}{l}\text { In online shopping of the above mentioned } \\
\text { products, it is difficult for me to judge product } \\
\text { quality adequately. }\end{array}$ & 3.81 & 1.01 \\
\hline COMPQUAL & $\begin{array}{l}\text { It is difficult for me to compare the quality of the } \\
\text { above-mentioned products in online shopping. }\end{array}$ & 4.02 & 0.86 \\
\hline NOTPERFM & $\begin{array}{l}\text { The above mentioned products if purchased online } \\
\text { may not perform as expected. }\end{array}$ & 3.55 & 1.02 \\
\hline NOTRECEIVE & I might not receive the product ordered online. & 3.96 & 0.97 \\
\hline RELIABILITY & $\begin{array}{l}\text { I am concerned about the reliability of online } \\
\text { shippers. }\end{array}$ & 3.43 & 1.15 \\
\hline CANTRECEIVE & I might not receive the product at appropriate time. & 3.91 & 1.06 \\
\hline OVERCHARGE & $\begin{array}{l}\text { I think in online shopping of the above-mentioned } \\
\text { products, I may get overcharged. }\end{array}$ & 3.79 & 1.09 \\
\hline GETCHEAP & It is almost not possible to get online a new & 3.39 & 1.25 \\
\hline
\end{tabular}




\begin{tabular}{|c|c|c|c|}
\hline & introduced product at cheap prices. & & \\
\hline \multirow[t]{2}{*}{ NOTRUST } & $\begin{array}{l}\text { I do not trust discounts and offers that are available } \\
\text { in online shopping for the above-mentioned } \\
\text { products. }\end{array}$ & 3.75 & 1.15 \\
\hline & B - TECHNOLOGY PRONENESS & & \\
\hline NEWTECHN & $\begin{array}{l}\text { The people come to me to get my advice on new } \\
\text { technologies }\end{array}$ & 3.77 & 1.24 \\
\hline TECHNOLOGY & $\begin{array}{l}\text { Technology gives people more control over their } \\
\text { daily lives. }\end{array}$ & 2.79 & 1.41 \\
\hline CONVENIENT & $\begin{array}{l}\text { Products and services that use new technologies } \\
\text { are more convenient to use. }\end{array}$ & 3.11 & 1.31 \\
\hline MOBILITY & Technology gives me the freedom of mobility.. & 2.39 & 1.30 \\
\hline \multirow[t]{2}{*}{ MOREEFFIC } & $\begin{array}{l}\text { Technology makes me more efficient in my } \\
\text { occupation. }\end{array}$ & 2.70 & 1.50 \\
\hline & C- RISK PERCEPTION AND RISK AVOIDANCE & & \\
\hline NOPROJECT & $\begin{array}{l}\text { When I start a project of my own, I sometimes think } \\
\text { that it is better to leave them alone rather t make a } \\
\text { mess of them. }\end{array}$ & 4.05 & 1.05 \\
\hline NOTREMOVE & $\begin{array}{l}\text { I always follow manufacturers warnings before } \\
\text { moving the back plates of electronic products. }\end{array}$ & 4.00 & 1.16 \\
\hline DIRECTIONS & $\begin{array}{l}\text { By using exact directions in the manuals about } \\
\text { usage of a sophisticated product I seldom succumb } \\
\text { into trouble. }\end{array}$ & 4.43 & 0.97 \\
\hline FAMILIAR & $\begin{array}{l}\text { I need not much instructions to use a product which } \\
\text { I am familiar with. }\end{array}$ & 4.18 & 1.03 \\
\hline AFRAIDTOBY & $\begin{array}{l}\text { I am afraid to buy a product which I don't know how } \\
\text { to use exactly. }\end{array}$ & 4.31 & 1.27 \\
\hline FEELUNEASY & $\begin{array}{l}\text { I mostly feel uneasy to set myself on projects which } \\
\text { I am not very much accustomed. }\end{array}$ & 4.48 & 0.98 \\
\hline
\end{tabular}




\begin{tabular}{|c|c|c|c|}
\hline FOLLOWINST & $\begin{array}{l}\text { I always follow the instructions of the manufacturers } \\
\text { when I start to use a sophisticated product. }\end{array}$ & 4.10 & 0.98 \\
\hline ASSEMBED & $\begin{array}{l}\text { I always buy furniture in assembled form, even } \\
\text { though unassembled forms costs much cheaper. }\end{array}$ & 3.66 & 1.70 \\
\hline IMPROVE & I constantly try to improve whatever I do. & 3.39 & 1.29 \\
\hline \multirow[t]{2}{*}{ NEWPRODUCT } & $\begin{array}{l}\text { I seldom buy a product which is just introduced to } \\
\text { the market since it might be expensive and apt to } \\
\text { product failures. }\end{array}$ & 4.09 & 1.79 \\
\hline & D - PHYSICAL RISK PERCEPTION & & \\
\hline DANGEROUS & $\begin{array}{l}\text { May be dangerous for me or some of my family } \\
\text { members. }\end{array}$ & 2.95 & 1.39 \\
\hline DMGHEALTH & Cheap hi-tech products could damage my health. & 2.88 & 1.44 \\
\hline NOTSAFE & $\begin{array}{l}\text { Such products would not be safe for me or my } \\
\text { family. }\end{array}$ & 2.53 & 1.28 \\
\hline PHYBCHRM & $\begin{array}{l}\text { I think an Apple iPod may cause me some physical } \\
\text { harm. }\end{array}$ & 2.53 & 1.29 \\
\hline \multirow[t]{2}{*}{ OLDTECHN } & Old technologies can be risky to human health. & 3.54 & 1.29 \\
\hline & E - CONSUMER INNOVATIVENESS & & \\
\hline GETADVICE & $\begin{array}{l}\text { Other people come to me to get my advice on new } \\
\text { hi-tech products.. }\end{array}$ & 3.12 & 1.27 \\
\hline NEWERTECHN & $\begin{array}{l}\text { It is evident that I am more adapted to newer } \\
\text { technologies than my friends. }\end{array}$ & 3.30 & 1.34 \\
\hline INNOVATOR & $\begin{array}{l}\text { In general, I am amongst the first in the cycle of my } \\
\text { friends to acquire new technologies when they } \\
\text { appear. }\end{array}$ & 3.25 & 1.38 \\
\hline NOTECHELP & $\begin{array}{l}\text { Generally I can figure out new technologies without } \\
\text { getting help from others. }\end{array}$ & 3.21 & 1.40 \\
\hline KEEPUPWITH & I can keep up with the latest technological & 2.29 & 1.31 \\
\hline
\end{tabular}




\begin{tabular}{|c|c|c|c|}
\hline & developments in my area of interest & & \\
\hline \multirow[t]{2}{*}{ LITTLETROUB } & $\begin{array}{l}\text { I am confronted with little trouble with respect to } \\
\text { other people in making technology work for me. }\end{array}$ & 3.61 & 1.32 \\
\hline & F- FUNCTIONAL RISK PERCEPTION & & \\
\hline SAFEPURCH & $\begin{array}{l}\text { Purchasing a well-known manufacturer brand is } \\
\text { safer than purchasing a well-known store brand. }\end{array}$ & 3.21 & 1.40 \\
\hline PERFBETTER & $\begin{array}{l}\text { A product with a "famous" manufacturer brand will } \\
\text { perform better than an store brand, even if the store } \\
\text { brand is from a reorganized establishment }\end{array}$ & 2.90 & 1.40 \\
\hline \multirow[t]{2}{*}{ WORSEPERFM } & $\begin{array}{l}\text { Store brands have worse performance than } \\
\text { manufacturer brands }\end{array}$ & 3.01 & 1.41 \\
\hline & G - INFORMATION SEEKING BEHAVIOR & & \\
\hline INFORSRCH & $\begin{array}{l}\text { I often search for information about new products } \\
\text { and brands. }\end{array}$ & 2.21 & 1,41 \\
\hline NEWBRNDS & $\begin{array}{l}\text { I frequently learn about new products and new } \\
\text { brands. }\end{array}$ & 2.81 & 1.27 \\
\hline MAGAZIN & $\begin{array}{l}\text { I like to read magazines which give place to new } \\
\text { products. }\end{array}$ & 2.31 & 1.27 \\
\hline INFORMATION & $\begin{array}{l}\text { I like to visit places where I can find information } \\
\text { about new products and new brands. }\end{array}$ & 3.16 & 1.44 \\
\hline \multirow[t]{2}{*}{ NEWPREXP } & I continuously look for new product experiences. & 2.59 & 1.39 \\
\hline & H - SOCIAL RISK PERCEPTION & & \\
\hline LOOKDOWN & $\begin{array}{l}\text { Continuous using of new technologies and } \\
\text { sophisticated products may make others look down } \\
\text { upon me. }\end{array}$ & 2.49 & 1.44 \\
\hline NEGTHOUGH & $\begin{array}{l}\text { Using too much sophisticated and expensive } \\
\text { products may negatively affect what the people } \\
\text { think of me. }\end{array}$ & 3.48 & 2.02 \\
\hline & & & \\
\hline
\end{tabular}




\begin{tabular}{|l|l|c|c|}
\hline & PART 6 CONSUMER DEMOGRAPHICS & & \\
\hline AGE & Age & 2.17 & 0.83 \\
\hline GENDER & Gender & $(\mathrm{X})$ & $(\mathrm{X})$ \\
\hline OCCUPATION & Occupation & $(\mathrm{X})$ & $(\mathrm{X})$ \\
\hline EDUCATION & Educational level & 2.42 & 0.69 \\
\hline INCOMELV & Income level & 2.37 & 1.04 \\
\hline
\end{tabular}

\section{(X) Placed on nominal scale}

It is evident from the table above that if the mean values assigned to variables are 3.00 , the respondents generally agree with the proposition given. On the other and, if these values are below 3.00, then the majority of them disagree.

\subsection{Distribution of Consumer Demographics}

As far as the consumer demographics are concerned, the following pie charts show how they are distributed as to the respondents:

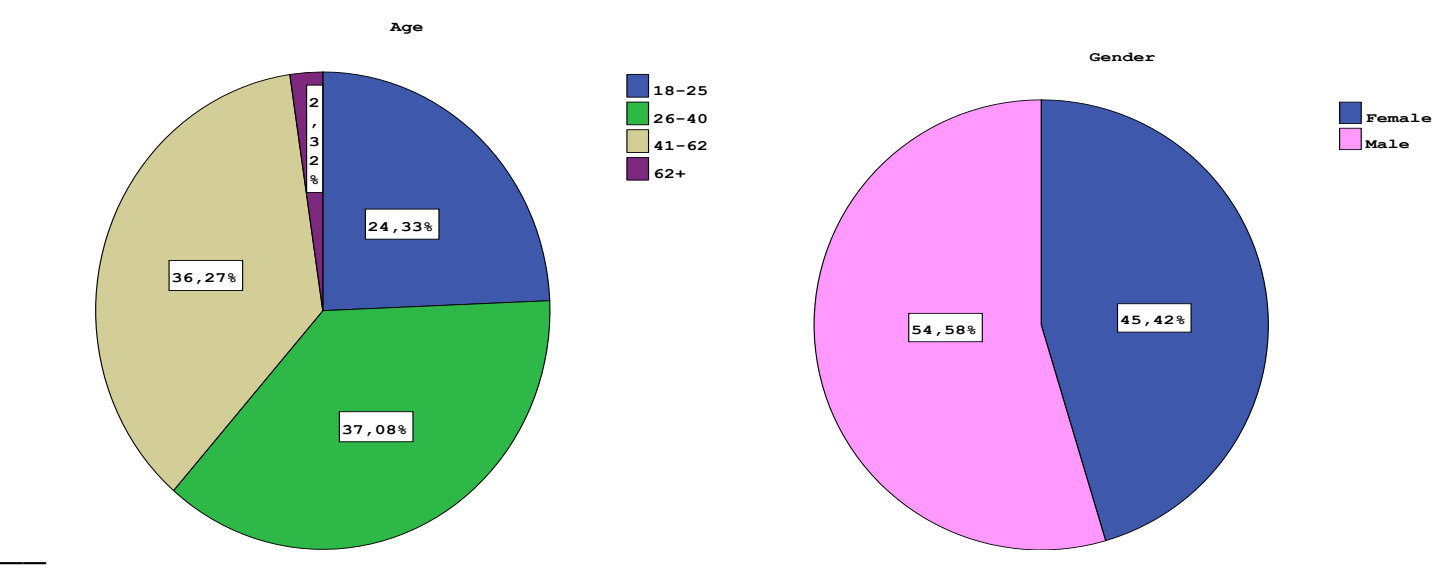



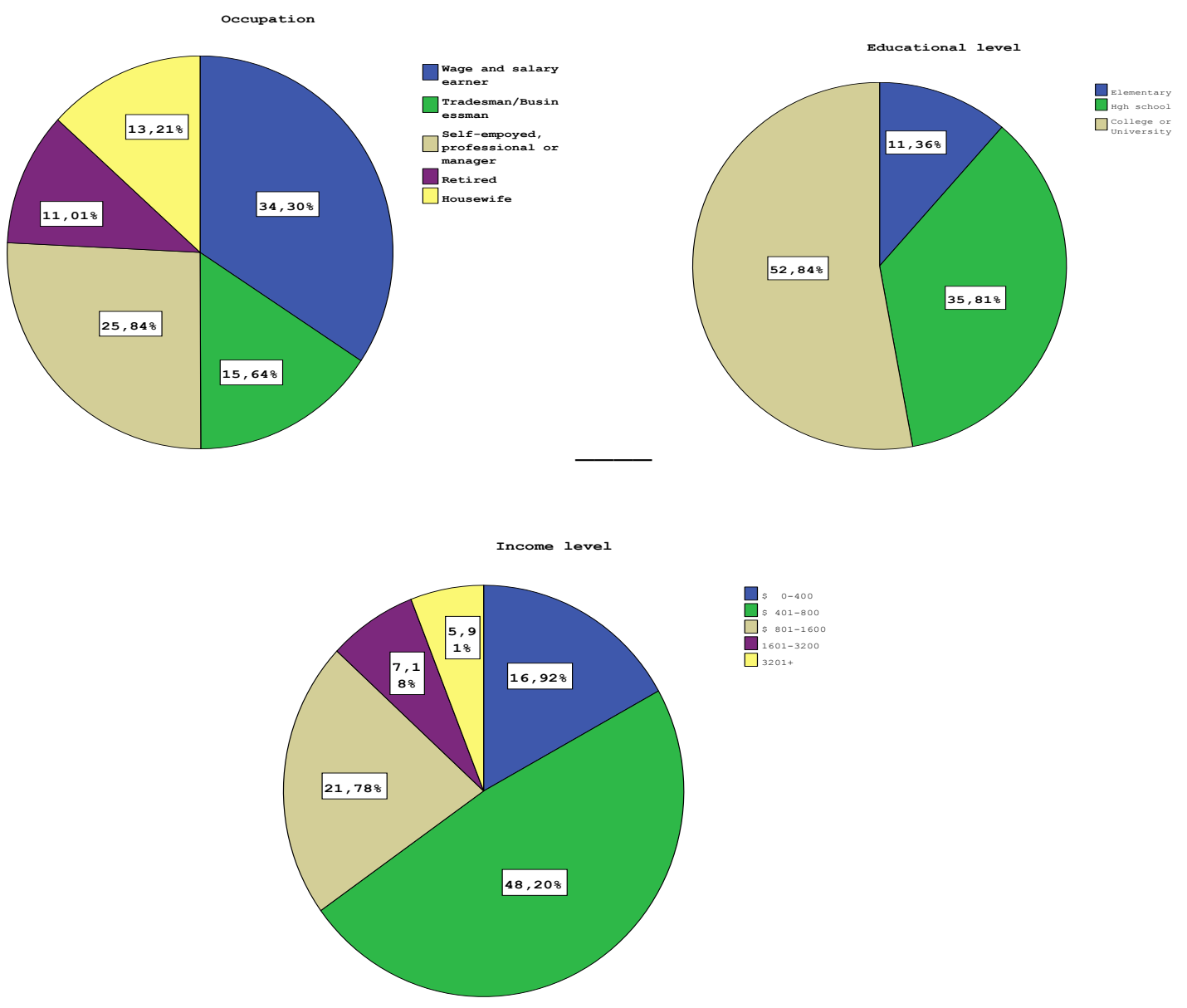

\subsection{Hypotheses}

Several research hypotheses are developed to be tested as follows:

H1: There is a Significant Negative (Inverse) Relationship Between Perceived Risks in Online Shopping and Technology Proneness.

H2: There is a Significant Positive Relationship Between Consumer Innovativeness and Information Seeking Behavior.

H3: Information Seeking Behavior is Negatively Correlated With Risk Perception and avoidance.

H4:Technology Prone Consumer Succumbs Least into Functional Risk Perception. H5:Demographic Characteristics of Consumers Differ Significantly With Respect to Innovativeness, Information Seeking Behavior and Risk Perception. 


\section{Analyses and Results}

\section{Hypotheses Tests Results}

Bi-variate analysis of test results proved the following results:

4.1 The Relationship Between Perceived Risks in Online Shopping and Technology Proneness.

Table 2. Relationship Between Perceived Risks in Online Shopping and Technology Proneness

\begin{tabular}{|c|c|c|c|c|c|c|}
\hline & \multicolumn{6}{|c|}{ Technology Proneness } \\
\hline & \multicolumn{2}{|c|}{$\begin{array}{l}\text { Other people come } \\
\text { to me to get my } \\
\text { advice on new } \\
\text { technologies }\end{array}$} & \multicolumn{2}{|c|}{$\begin{array}{l}\text { Technology gives } \\
\text { people more control } \\
\text { over their daily lives }\end{array}$} & \multicolumn{2}{|c|}{$\begin{array}{l}\text { Products and services } \\
\text { that use new } \\
\text { technologies are more } \\
\text { convenient to use. }\end{array}$} \\
\hline & $\begin{array}{c}\text { Agree } \\
\%\end{array}$ & Disagree \% & $\begin{array}{c}\text { Agree } \\
\%\end{array}$ & Disagree \% & $\begin{array}{c}\text { Agree } \\
\%\end{array}$ & Disagree \% \\
\hline $\begin{array}{l}\text { Perceived } \\
\text { Risks in } \\
\text { Online } \\
\text { Shopping }\end{array}$ & & & & & & \\
\hline $\begin{array}{l}\text { In online } \\
\text { shopping of the } \\
\text { above } \\
\text { mentioned } \\
\text { products, it is } \\
\text { difficult for me } \\
\text { to judge } \\
\text { product quality } \\
\text { adequately. }\end{array}$ & $\begin{array}{l}61.6 \\
83.9\end{array}$ & $\begin{array}{l}24.0 \\
10.7\end{array}$ & $\begin{array}{l}26.2 \\
74.8\end{array}$ & $\begin{array}{l}56.0 \\
10.7\end{array}$ & $\begin{array}{l}42.2 \\
77.5\end{array}$ & $\begin{array}{l}36.0 \\
14.5\end{array}$ \\
\hline $\begin{array}{l}\text { It is difficult for } \\
\text { me to compare } \\
\text { the quality of } \\
\text { the above- } \\
\text { mentioned } \\
\text { products in } \\
\text { online }\end{array}$ & $\begin{array}{l}62.8 \\
89.3\end{array}$ & $\begin{array}{c}45.5 \\
7.2\end{array}$ & $\begin{array}{l}24.1 \\
85.2\end{array}$ & $\begin{array}{c}54.6 \\
6.2\end{array}$ & $\begin{array}{l}51.0 \\
83.4\end{array}$ & $\begin{array}{l}36.4 \\
12.3\end{array}$ \\
\hline
\end{tabular}




\begin{tabular}{|l|l|l|l|l|l|l|}
\hline shopping. & & & & & & \\
\hline $\begin{array}{l}\text { The above } \\
\text { mentioned } \\
\text { products if } \\
\text { purchased } \\
\text { online may not } \\
\text { perform as } \\
\text { expected. }\end{array}$ & 73.2 & 10.7 & 81.7 & 14.4 & 39.1 & 43.4 \\
\hline
\end{tabular}

Accepted at $\square<0.01$

$\mathrm{H} 1$ is accepted at all levels of online shopping risks and technology proneness. This conclusion is also revealed in the following histograms of the two $s$ variables with the factor loadings from each component:



Ther people come to me to get my advice on new technologies

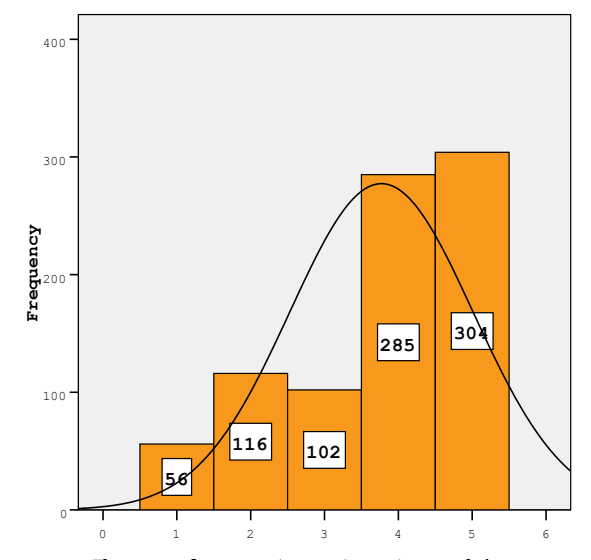

Ther people come to me to get my advice on

new technologies

4.2 The Relationship Between Consumer Innovativeness and Information Seeking Behavior. 
Table 3. Relationship Between Consumer Innovativeness and Information Seeking Behavior.

\begin{tabular}{|c|c|c|c|c|c|c|}
\hline & \multicolumn{6}{|c|}{ Consumer Innovativeness } \\
\hline & \multicolumn{2}{|c|}{$\begin{array}{l}\text { Other people come to } \\
\text { me to get my advice on } \\
\text { new hi-tech products }\end{array}$} & \multicolumn{2}{|c|}{$\begin{array}{l}\text { It is evident that I am } \\
\text { more adapted to newer } \\
\text { technologies than my } \\
\text { friends. }\end{array}$} & \multicolumn{2}{|c|}{$\begin{array}{l}\text { In general, I am } \\
\text { amongst the first in the } \\
\text { cycle of my friends to } \\
\text { acquire new } \\
\text { technologies when } \\
\text { they appear. }\end{array}$} \\
\hline & $\begin{array}{c}\text { Agree } \\
\%\end{array}$ & Disagree \% & $\begin{array}{c}\text { Agree } \\
\%\end{array}$ & Disagree \% & $\begin{array}{c}\text { Agree } \\
\text { \% }\end{array}$ & Disagree \% \\
\hline $\begin{array}{l}\text { Information } \\
\text { Seeking } \\
\text { Behavior }\end{array}$ & & & & & & \\
\hline $\begin{array}{l}\text { I often search } \\
\text { for information } \\
\text { about new } \\
\text { products and } \\
\text { brands. }\end{array}$ & $\begin{array}{l}53.5 \\
13.7\end{array}$ & $\begin{array}{r}40.5 \\
71.2 \\
(X)\end{array}$ & $\begin{array}{l}48.8 \\
24.2\end{array}$ & $\begin{array}{l}31.5 \\
71.1 \\
(X)\end{array}$ & $\begin{array}{l}60.5 \\
16.3\end{array}$ & $\begin{array}{l}35.1 \\
69.0 \\
(X)\end{array}$ \\
\hline $\begin{array}{l}\text { I frequently } \\
\text { learn about new } \\
\text { products and } \\
\text { new brands. }\end{array}$ & $\begin{array}{l}44.3 \\
49.1\end{array}$ & $\begin{array}{l}39.0 \\
43.9\end{array}$ & $\begin{array}{l}62.0 \\
36.7\end{array}$ & $\begin{array}{l}42.7 \\
52.4 \\
(X)\end{array}$ & $\begin{array}{l}64.5 \\
34.7\end{array}$ & $\begin{array}{l}43.4 \\
52.1 \\
(X)\end{array}$ \\
\hline $\begin{array}{l}\text { I like to read } \\
\text { magazines } \\
\text { which give place } \\
\text { to new } \\
\text { products. }\end{array}$ & $\begin{array}{l}40.0 \\
29.4\end{array}$ & $\begin{array}{l}33.5 \\
56.2 \\
(X)\end{array}$ & $\begin{array}{l}41.7 \\
25.8\end{array}$ & $\begin{array}{l}35.2 \\
64.8 \\
(X)\end{array}$ & $\begin{array}{l}53.4 \\
29.5\end{array}$ & $\begin{array}{l}34.8 \\
63.5 \\
(X)\end{array}$ \\
\hline
\end{tabular}

Accepted at $\square<0.01$

(X) Inversely correlated

$\mathrm{H} 2$ is rejected almost at all levels (eight out of nine) of the cases prove a negative relationships between these two groups of variables. The following histograms prove this negative relationship: 

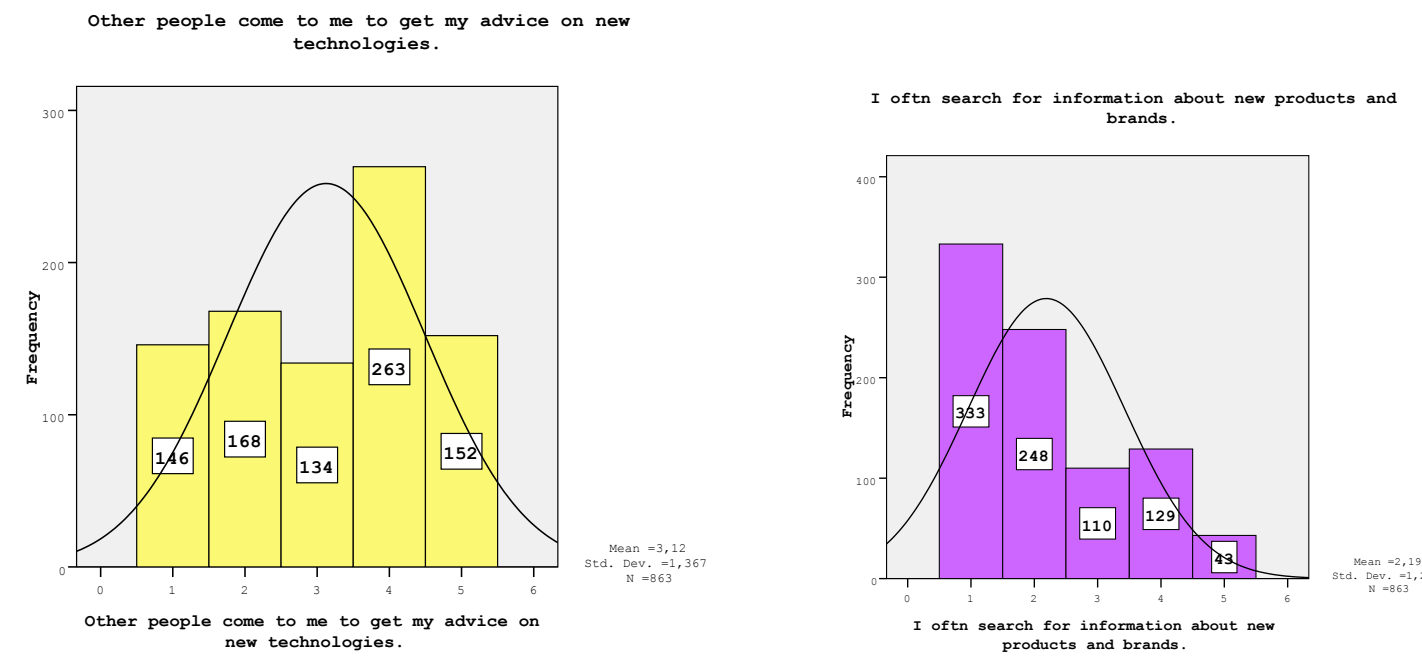

4.3 The Relationship Between Information Seeking Behavior and Risk Avoidance.

Table 4. Relationship Between Information Seeking Behavior and Risk Perception and Avoidance

\begin{tabular}{|c|c|c|c|c|c|c|}
\hline & \multicolumn{6}{|c|}{ Risk Perception and Avoidance } \\
\hline & \multicolumn{2}{|c|}{$\begin{array}{l}\text { When I start a project } \\
\text { of my own, I } \\
\text { sometimes think that it } \\
\text { is better to leave them } \\
\text { alone rather to make a } \\
\text { mess of them. }\end{array}$} & \multicolumn{2}{|c|}{$\begin{array}{l}\text { I always follow } \\
\text { manufacturers } \\
\text { warnings before } \\
\text { moving the back } \\
\text { plates of electronic } \\
\text { products }\end{array}$} & \multicolumn{2}{|c|}{$\begin{array}{l}\text { By using exact directions in } \\
\text { the manuals about usage of } \\
\text { a sophisticated product I } \\
\text { seldom succumb into } \\
\text { trouble.. }\end{array}$} \\
\hline & $\begin{array}{c}\text { Agree } \\
\%\end{array}$ & Disagree $\%$ & $\begin{array}{c}\text { Agree } \\
\%\end{array}$ & Disagree \% & $\begin{array}{c}\text { Agree } \\
\%\end{array}$ & Disagree \% \\
\hline $\begin{array}{l}\text { Information } \\
\text { Seeking } \\
\text { Behavior }\end{array}$ & & & & & & \\
\hline $\begin{array}{l}\text { I often search } \\
\text { for } \\
\text { information } \\
\text { about new } \\
\text { products and }\end{array}$ & $\begin{array}{l}76.7 \\
18.2\end{array}$ & $\begin{array}{c}9.0 \\
54.6\end{array}$ & $\begin{array}{l}79.1 \\
19.5\end{array}$ & $\begin{array}{l}14.4 \\
71.7\end{array}$ & $\begin{array}{c}\text { Not } \\
\text { Sustained }\end{array}$ & $\begin{array}{c}\text { Not } \\
\text { Sustained }\end{array}$ \\
\hline
\end{tabular}




\begin{tabular}{|l|c|c|c|c|c|c|}
\hline brands. & & & & & & \\
\hline $\begin{array}{l}\text { I frequently } \\
\text { learn about } \\
\text { new products } \\
\text { and new } \\
\text { brands. }\end{array}$ & 54.6 & 36.3 & 43.5 & 41.3 & 50.0 & 40.01 \\
\hline $\begin{array}{l}\text { I like to read } \\
\text { magazines } \\
\text { which give } \\
\text { place to new } \\
\text { products. }\end{array}$ & 61.7 & 3.7 & 83.3 & 11.7 & $\begin{array}{c}\text { Not } \\
\text { (XX) }\end{array}$ & $\begin{array}{c}\text { Not } \\
\text { Sustained }\end{array}$ \\
\hline
\end{tabular}

(XX) Accepted at $\square<0.05$

As could be seen above $\mathrm{H} 3$ is accepted at all levels of the two variables. The distributions of the variables are given below:

When I start a project of my own, I sometimes think that it is better to leave them alone rather $t$ make a mess of them.
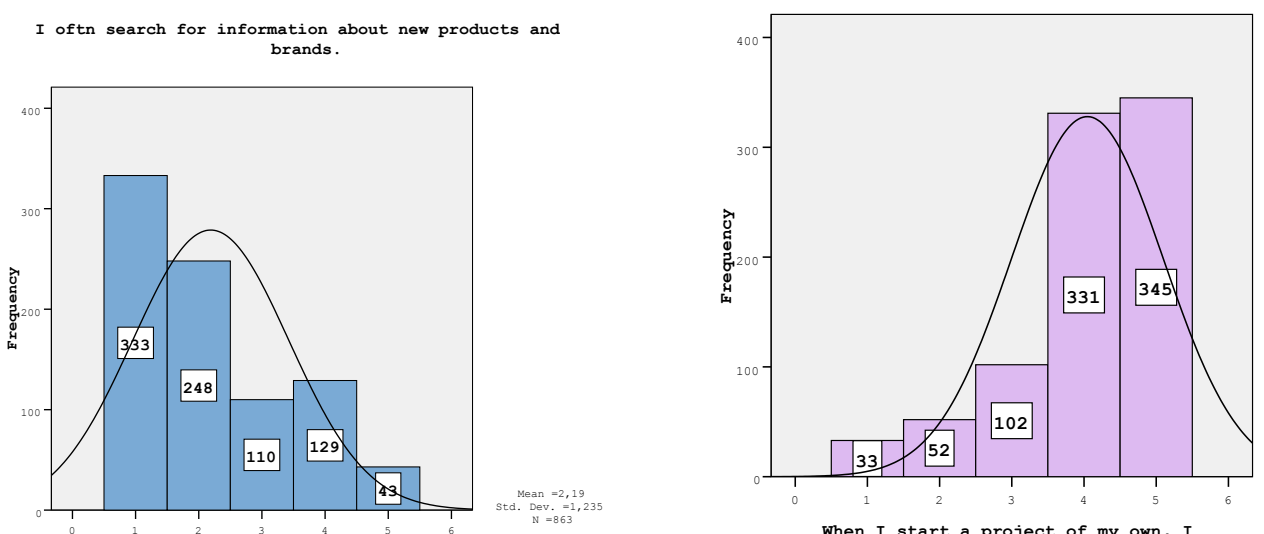

I oftn search for information about new
products and brands.

When I start a project of my own, I sometimes think that it is better to leave alone rather $t$ make a mess of them.

4.4 The Relationship Between Technology Proneness and Functional Risk Perception. 
Table 5. Relationship Between Technology Proneness and Functional Risk Perception

\begin{tabular}{|c|c|c|c|c|c|c|}
\hline & \multicolumn{6}{|c|}{ Technology Proneness } \\
\hline & \multicolumn{2}{|c|}{$\begin{array}{l}\text { Other people come } \\
\text { to me to get my } \\
\text { advice on new } \\
\text { technologies }\end{array}$} & \multicolumn{2}{|c|}{$\begin{array}{l}\text { Technology gives } \\
\text { people more control } \\
\text { over their daily lives }\end{array}$} & \multicolumn{2}{|c|}{$\begin{array}{l}\text { Products and services } \\
\text { that use new } \\
\text { technologies are more } \\
\text { convenient to use. }\end{array}$} \\
\hline & $\begin{array}{c}\text { Agree } \\
\%\end{array}$ & Disagree \% & $\begin{array}{c}\text { Agree } \\
\%\end{array}$ & Disagree \% & $\begin{array}{c}\text { Agree } \\
\%\end{array}$ & Disagree \% \\
\hline $\begin{array}{l}\text { Functional } \\
\text { Risk } \\
\text { Perception }\end{array}$ & & & & & & \\
\hline $\begin{array}{l}\text { Purchasing a } \\
\text { well-known } \\
\text { manufacturer } \\
\text { brand is safer } \\
\text { than purchasing } \\
\text { a well-known } \\
\text { store brand. }\end{array}$ & $\begin{array}{l}43.0 \\
66.4\end{array}$ & $\begin{array}{l}26.0 \\
23.2\end{array}$ & $\begin{array}{l}35.8 \\
57.9\end{array}$ & $\begin{array}{l}46.4 \\
29.8\end{array}$ & $\begin{array}{l}45.9 \\
63.0\end{array}$ & $\begin{array}{l}35.4 \\
32.6\end{array}$ \\
\hline $\begin{array}{l}\text { A product with a } \\
\text { "famous" } \\
\text { manufacturer } \\
\text { brand will } \\
\text { perform better } \\
\text { than an store } \\
\text { brand, even if } \\
\text { the store brand } \\
\text { is from a } \\
\text { reorganized } \\
\text { establishment }\end{array}$ & $\begin{array}{l}39.8 \\
61.0\end{array}$ & $\begin{array}{l}22.9 \\
30.2\end{array}$ & $\begin{array}{l}33.3 \\
46.6\end{array}$ & $\begin{array}{l}45.2 \\
39.9\end{array}$ & $\begin{array}{l}49.7 \\
50.0\end{array}$ & $\begin{array}{l}30.3 \\
39.8 \\
(X)\end{array}$ \\
\hline $\begin{array}{l}\text { Store brands } \\
\text { have worse } \\
\text { performance }\end{array}$ & $\begin{array}{l}48.0 \\
53.5\end{array}$ & $\begin{array}{l}39.2 \\
46.3\end{array}$ & $\begin{array}{l}38.8 \\
45.7\end{array}$ & $\begin{array}{l}51.9 \\
38.5\end{array}$ & $\begin{array}{l}56.9 \\
50.7\end{array}$ & $\begin{array}{l}39.3 \\
47.8\end{array}$ \\
\hline
\end{tabular}




\begin{tabular}{|l|l|l|l|l|l|}
\hline $\begin{array}{l}\text { than } \\
\text { manufacturer } \\
\text { brands }\end{array}$ & & $(\mathrm{X})$ & & & \\
\hline
\end{tabular}

\section{(X) Positively correlated}

$\mathrm{H} 4$ is accepted at seven levels out of nine relationship between the variables of 'functional risk perception' and 'technology proneness'. However the discrepancy between thebe two variables is not very much stressed as in the preceding hypotheses. Following distributions prove this situation:
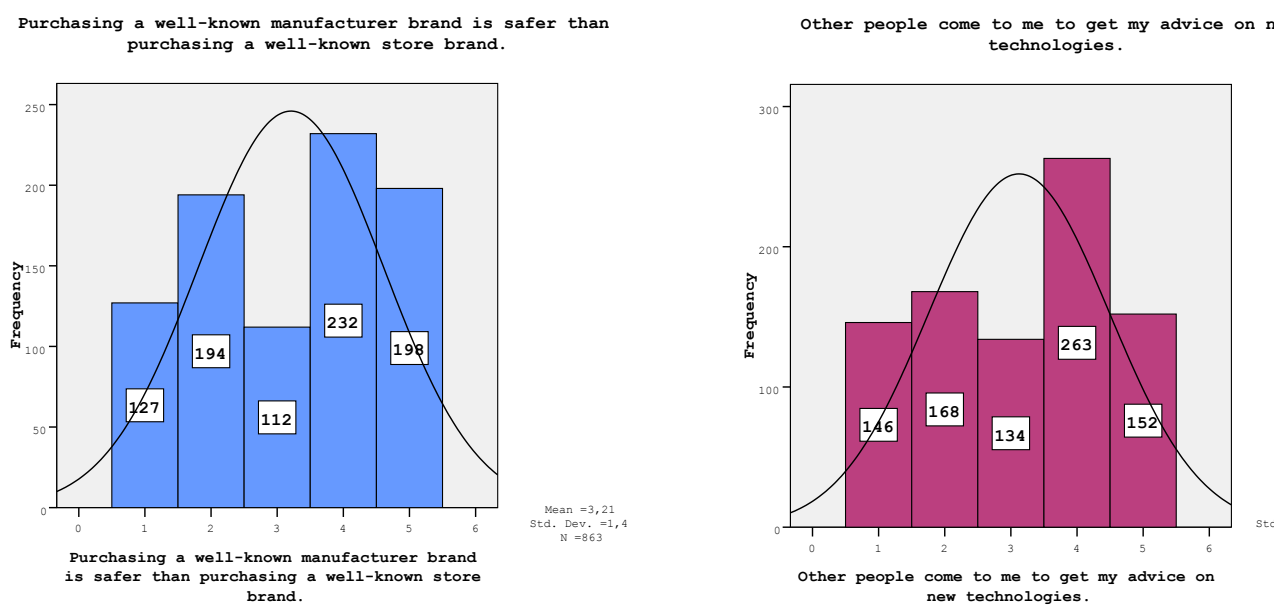

4.5 The Demographic Characteristics of the Consumers in Conformity With Their Innovativeness, Information Seeking Behavior and Risk Perception.

Table 6. Demographic Characteristics of the Consumers in Conformity With Their Innovativeness, Information Seeking Behavior and Risk Perception.

\begin{tabular}{|c|c|c|c|c|c|}
\hline & \multicolumn{5}{|c|}{ Consumer Demographics } \\
\hline $\begin{array}{c}\text { Risk Perceptions, } \\
\text { Innovativeness and } \\
\text { Information Seeking Behavior }\end{array}$ & Age & Gender & Occupation & $\begin{array}{l}\text { Education } \\
\text { Level }\end{array}$ & Income Level \\
\hline $\begin{array}{l}\text { A - PERCEIVED RISKS IN ONLINE } \\
\text { SHOPPING }\end{array}$ & & & & & \\
\hline $\begin{array}{l}\text { In online shopping of the above } \\
\text { mentioned products, it is difficult for } \\
\text { me to judge product quality }\end{array}$ & $\begin{array}{c}\text { Not } \\
\text { Sustained }\end{array}$ & $\begin{array}{c}\text { Not } \\
\text { Sustained }\end{array}$ & $\begin{array}{c}\text { Not } \\
\text { Sustained }\end{array}$ & $\begin{array}{c}\text { Not } \\
\text { Sustained }\end{array}$ & $\begin{array}{c}\text { Not } \\
\text { Sustained }\end{array}$ \\
\hline
\end{tabular}




\begin{tabular}{|c|c|c|c|c|c|}
\hline adequately. & & & & & \\
\hline $\begin{array}{l}\text { It is difficult for me to compare the } \\
\text { quality of the above-mentioned } \\
\text { products in online shopping. }\end{array}$ & $\begin{array}{l}\text { Not } \\
\text { Sustained }\end{array}$ & $\begin{array}{l}\text { Female } \\
85.5 \% \\
(\mathrm{XX})\end{array}$ & $\begin{array}{c}\text { Not } \\
\text { Sustained }\end{array}$ & $\begin{array}{l}\text { Not } \\
\text { Sustained }\end{array}$ & $\begin{array}{l}\text { Not } \\
\text { Sustained }\end{array}$ \\
\hline $\begin{array}{l}\text { The above mentioned products if } \\
\text { purchased online may not perform as } \\
\text { expected. }\end{array}$ & $\begin{array}{c}\text { Not } \\
\text { Sustained }\end{array}$ & $\begin{array}{c}\text { Not } \\
\text { Sustained }\end{array}$ & $\begin{array}{c}\text { Not } \\
\text { Sustained }\end{array}$ & $\begin{array}{c}\text { Not } \\
\text { Sustained }\end{array}$ & $\begin{array}{c}\$ 1601-300 \\
72.6 \%\end{array}$ \\
\hline \multicolumn{6}{|l|}{ B - TECHNOLOGY PRONENESS } \\
\hline $\begin{array}{l}\text { The people come to me to get my } \\
\text { advice on new technologies }\end{array}$ & $\begin{array}{c}\text { Not } \\
\text { Sustained }\end{array}$ & $\begin{array}{c}\text { Not } \\
\text { Sustained }\end{array}$ & $\begin{array}{l}\text { Housewive } \\
\text { s } 76.3 \%\end{array}$ & $\begin{array}{c}\text { Elementary } \\
\quad 78.6 \%\end{array}$ & $\begin{array}{l}\$ 3200 \\
75.0 \%\end{array}$ \\
\hline $\begin{array}{l}\text { Technology gives people more control } \\
\text { over their daily lives. }\end{array}$ & $\begin{array}{l}41-62 \\
48.9 \%\end{array}$ & $\begin{array}{c}\text { Not } \\
\text { Sustained }\end{array}$ & $\begin{array}{c}\text { Not } \\
\text { Sustained }\end{array}$ & $\begin{array}{l}\text { Middle } \\
\text { School } \\
43.7 \%\end{array}$ & $\begin{array}{l}\$ 0-400 \\
43.2 \%\end{array}$ \\
\hline $\begin{array}{l}\text { Products and services that use new } \\
\text { technologies are more convenient to } \\
\text { use. }\end{array}$ & $\begin{array}{l}18-25 \\
49.5 \%\end{array}$ & $\begin{array}{c}\text { Not } \\
\text { Sustained }\end{array}$ & $\begin{array}{l}\text { Wage and } \\
\text { Salary } \\
\text { Earners } \\
52.1 \%(X X)\end{array}$ & $\begin{array}{l}\text { Middle } \\
\text { School } 50.5 \% \\
(X X)\end{array}$ & $\begin{array}{l}\$ 0-400 \\
58.9 \%\end{array}$ \\
\hline \multicolumn{6}{|l|}{$\begin{array}{l}\text { C- RISK PERCEPTION AND RISK } \\
\text { AVOIDANCE }\end{array}$} \\
\hline $\begin{array}{l}\text { When I start a project of my own, I } \\
\text { sometimes think that it is better to } \\
\text { leave them alone rather t make a } \\
\text { mess of them. }\end{array}$ & $\begin{array}{c}\text { Not } \\
\text { Sustained }\end{array}$ & $\begin{array}{l}\text { Females } \\
85.5 \%\end{array}$ & $\begin{array}{l}\text { Housewive } \\
\text { s } 85.0 \%\end{array}$ & $\begin{array}{c}\text { Not } \\
\text { Sustained }\end{array}$ & Not Sustained \\
\hline $\begin{array}{l}\text { I always follow manufacturers } \\
\text { warnings before moving the back } \\
\text { plates of electronic products. }\end{array}$ & $\begin{array}{c}\text { Not } \\
\text { Sustained }\end{array}$ & $\begin{array}{c}\text { Not } \\
\text { Sustained }\end{array}$ & $\begin{array}{c}\text { Not } \\
\text { Sustained }\end{array}$ & $\begin{array}{l}\text { College- } \\
\text { University } \\
77.1 \%\end{array}$ & $\begin{array}{l}\% 1601-3200 \\
86.7 \%\end{array}$ \\
\hline $\begin{array}{l}\text { By using exact directions in the } \\
\text { manuals about usage of a } \\
\text { sophisticated product I seldom } \\
\text { succumb into trouble. }\end{array}$ & $\begin{array}{c}\text { Not } \\
\text { Sustained }\end{array}$ & $\begin{array}{c}\text { Not } \\
\text { Sustained }\end{array}$ & $\begin{array}{c}\text { Not } \\
\text { Sustained }\end{array}$ & $\begin{array}{l}\text { Elementary } \\
7.8 \%\end{array}$ & Not Sustained \\
\hline D - PHYSICAL RISK PERCEPTION & & & & & \\
\hline
\end{tabular}




\begin{tabular}{|c|c|c|c|c|c|}
\hline $\begin{array}{l}\text { May be dangerous for me or some of } \\
\text { my family members. }\end{array}$ & $\begin{array}{l}26-40 \\
51.3 \%\end{array}$ & $\begin{array}{l}\text { Not } \\
\text { Sustained }\end{array}$ & $\begin{array}{l}\text { Self- } \\
\text { employed } \\
54.3 \%\end{array}$ & $\begin{array}{l}\text { College- } \\
\text { University } \\
50.0 \%\end{array}$ & $\begin{array}{l}\$ 1601-3200 \\
61.3 \%\end{array}$ \\
\hline $\begin{array}{l}\text { Cheap hi-tech products could damage } \\
\text { my health. }\end{array}$ & $\begin{array}{l}\text { Not } \\
\text { Sustained }\end{array}$ & $\begin{array}{l}\text { Females } \\
41.6 \% \\
(X X)\end{array}$ & $\begin{array}{l}\text { Wage and } \\
\text { Salary } \\
\text { Earners } \\
72.1 \%\end{array}$ & $\begin{array}{l}\text { Not } \\
\text { Sustained }\end{array}$ & Not Sustained \\
\hline $\begin{array}{l}\text { Such products would not be safe for } \\
\text { me or my family. }\end{array}$ & $\begin{array}{l}26-40 \\
32.5 \%\end{array}$ & $\begin{array}{l}\text { Not } \\
\text { Sustained }\end{array}$ & $\begin{array}{l}\text { Not } \\
\text { Sustained }\end{array}$ & $\begin{array}{l}\text { Not } \\
\text { Sustained }\end{array}$ & $\begin{array}{l}\$ 801-1600 \\
30.5 \%\end{array}$ \\
\hline \multicolumn{6}{|l|}{ E - CONSUMER INNOVATIVENESS } \\
\hline $\begin{array}{l}\text { Other people come to me to get my } \\
\text { advice on new hi-tech products.. }\end{array}$ & $\begin{array}{l}41-62 \\
57.8 \%(x x)\end{array}$ & $\begin{array}{l}\text { Females } \\
54.1 \%\end{array}$ & $\begin{array}{l}\text { Retired } \\
61.9 \%\end{array}$ & $\begin{array}{l}\text { Elementary } \\
60.1 \%\end{array}$ & $\begin{array}{l}\$ 0-400 \\
52.8 \%\end{array}$ \\
\hline $\begin{array}{l}\text { It is evident that I am more adapted to } \\
\text { newer technologies than my friends. }\end{array}$ & $\begin{array}{l}\text { Not } \\
\text { Sustained }\end{array}$ & $\begin{array}{l}\text { Not } \\
\text { Sustained }\end{array}$ & $\begin{array}{l}\text { Retired } \\
64.0 \%\end{array}$ & $\begin{array}{l}\text { Elementary } \\
61.2 \%\end{array}$ & $\begin{array}{l}\$ 0-400 \\
65.1 \%\end{array}$ \\
\hline $\begin{array}{l}\text { In general, I am amongst the first in } \\
\text { the cycle of my friends to acquire new } \\
\text { technologies when they appear. }\end{array}$ & $\begin{array}{l}62- \\
70.0 \%\end{array}$ & $\begin{array}{l}\text { Not } \\
\text { Sustained }\end{array}$ & $\begin{array}{l}\text { Wage and } \\
\text { Salary } \\
\text { Earners } \\
58.1 \%\end{array}$ & $\begin{array}{l}\text { Elementary } \\
62.3 \%\end{array}$ & Not Sustained \\
\hline \multicolumn{6}{|l|}{ F- FUNCTIONAL RISK PERCEPTION } \\
\hline $\begin{array}{l}\text { Purchasing a well-known } \\
\text { manufacturer brand is safer than } \\
\text { purchasing a well-known store brand. }\end{array}$ & $\begin{array}{l}62- \\
55.0 \%\end{array}$ & $\begin{array}{c}\text { Not } \\
\text { Sustained }\end{array}$ & $\begin{array}{c}\text { Not } \\
\text { Sustained }\end{array}$ & $\begin{array}{c}\text { Not } \\
\text { Sustained }\end{array}$ & Not Sustained \\
\hline $\begin{array}{l}\text { A product with a "famous" } \\
\text { manufacturer brand will perform better } \\
\text { than an store brand, even if the store } \\
\text { brand is from a reorganized } \\
\text { establishment }\end{array}$ & $\begin{array}{c}\text { Not } \\
\text { Sustained }\end{array}$ & $\begin{array}{c}\text { Not } \\
\text { Sustained }\end{array}$ & $\begin{array}{c}\text { Not } \\
\text { Sustained }\end{array}$ & $\begin{array}{l}\text { Elementary } \\
\mathbf{5 0 . 0 \%}\end{array}$ & Not Sustained \\
\hline $\begin{array}{l}\text { Store brands have worse } \\
\text { performance than manufacturer } \\
\text { brands }\end{array}$ & $\begin{array}{c}\text { Not } \\
\text { Sustained }\end{array}$ & $\begin{array}{c}\text { Not } \\
\text { Sustained }\end{array}$ & $\begin{array}{c}\text { Not } \\
\text { Sustained }\end{array}$ & $\begin{array}{l}\text { College- } \\
\text { University } \\
49.5 \%\end{array}$ & Not Sustained \\
\hline $\begin{array}{l}\text { G - INFORMATION SEEKING } \\
\text { BEHAVIOR }\end{array}$ & & & & & \\
\hline
\end{tabular}




\begin{tabular}{|c|c|c|c|c|c|}
\hline $\begin{array}{l}\text { I often search for information about } \\
\text { new products and brands. }\end{array}$ & $\begin{array}{l}\text { Not } \\
\text { Sustained }\end{array}$ & $\begin{array}{l}\text { Males } \\
21.0 \%\end{array}$ & $\begin{array}{l}\text { Wage and } \\
\text { Salary } \\
\text { Earners } \\
23.3 \%\end{array}$ & $\begin{array}{l}\text { Middle } \\
\text { School } \\
23.7 \%\end{array}$ & $\begin{array}{l}\$ 3200- \\
26.4 \%\end{array}$ \\
\hline $\begin{array}{l}\text { I frequently learn about new products } \\
\text { and new brands. }\end{array}$ & $\begin{array}{l}\text { Not } \\
\text { Sustained }\end{array}$ & $\begin{array}{c}\text { Not } \\
\text { Sustained }\end{array}$ & $\begin{array}{c}\text { Not } \\
\text { Sustained }\end{array}$ & $\begin{array}{l}\text { Elementary } \\
42.8 \%(X X)\end{array}$ & Not Sustained \\
\hline $\begin{array}{l}\text { I like to read magazines which give } \\
\text { place to new products. }\end{array}$ & $\begin{array}{l}\text { Not } \\
\text { Sustained }\end{array}$ & $\begin{array}{l}\text { Females } \\
21.9 \%\end{array}$ & $\begin{array}{l}\text { Not } \\
\text { Sustained }\end{array}$ & $\begin{array}{l}\text { Elementary } \\
29.6 \%\end{array}$ & Not Sustained \\
\hline \multicolumn{6}{|l|}{ H - SOCIAL RISK PERCEPTION } \\
\hline $\begin{array}{l}\text { Continuous using of new technologies } \\
\text { and sophisticated products may make } \\
\text { others look down upon me. }\end{array}$ & $\begin{array}{l}\text { Not } \\
\text { Sustained }\end{array}$ & $\begin{array}{l}\text { Females } \\
33.3 \%\end{array}$ & $\begin{array}{c}\text { Not } \\
\text { Sustained }\end{array}$ & $\begin{array}{c}\text { Not } \\
\text { Sustained }\end{array}$ & Not Sustained \\
\hline $\begin{array}{l}\text { Using too much sophisticated and } \\
\text { expensive products may negatively } \\
\text { affect what the people think of me. }\end{array}$ & $\begin{array}{l}\text { Not } \\
\text { Sustained }\end{array}$ & $\begin{array}{l}\text { Females } \\
69.1 \%\end{array}$ & $\begin{array}{l}\text { Housewive } \\
\text { s } 67.5 \%\end{array}$ & & $\begin{array}{c}\$ 1601-3200 \\
59.0 \%\end{array}$ \\
\hline & & & & & \\
\hline
\end{tabular}

(XX) Accepted at $\square<0.05$

\subsection{Factor Analysis}

An exploratory factor analysis reduces 45 variables to eight basic components as shown in Table 1. KMO test of sampling adequacy and scale reliability test proved high scores as 0.835 and 0.7311 respectively:

\section{Conclusion}

The pragmatic approach of this paper first of all proved the inverse relationship between perceived risks and technology proneness of the consumers who purchase and use high-tech products. The proposition "technology gives people more control over their daily lives" proved that people may succumb less to 'risk-anxiety' if they properly cope with new technologies.

It is perplexing that the findings proved the contrary of what was anticipated as far as the relationship between consumer innovativeness and consumer information seeking behavior is concerned. The pre-though positive relationship turned out to be negative for most of the cases and the writers of this paper could not find a plausible reason for it except the divergent assumption that 'innovators do not need too much information to be triggered by the attraction of new and sophisticated products". 
However, information seeking behavior pulled up caught its conventional function, when related to risk perception and risk avoidance. Here this relationship proved to be solid and the inverse relationship is evident at almost all levels of the analyses. "More information yields less perception of risks" is the motto of this comparison.

One of the important findings of this study is that technology-prone people do not care much about perceiving functional risks. They believe that they can command technologies rather than be embarred...

Finally from 'consumer demographics' point of view some outstanding conclusions are found as follows:

a. Females and upper-middle income class perceive risks in online shopping.

b. Youngsters, white and blue collar workers, middle school graduates and lowest income group are technologically prone.

c. Risk perception and risk avoidance is more common among females, housewives, college and university graduates and upper-middle income group.

d. Young adults, females, self-employed and white and blue collar workers, university graduates and middle income people care abut physical risks more than other people.

e. Mature and elderly people, females, retirees, wage and salary earners elementary school graduates and lowest income people see themselves as innovative consumers.

f. Functional risk is perceived mainly by elderly people and university graduates.

g. Information-seeking behavior is common amongst wage and salary earners and highest income group.

h. Social risk is perceived by females, housewives and higher income group.

\section{References}

Baumgartner, H. and Steenkamp, J. (1996), "Exploratory consumer buying behavior: conceptualization and measurement", International Journal of Research in Marketing, Vol. 13 No. 2, pp. 121-37. http://dx.doi.org/10.1016/0167-8116(95)00037-2

Cotte, J. and Wood, S.L. (2004), "Families and innovative consumer behavior: a triadic analysis of sibling and parental influence", Journal of Consumer Research, Vol. 31 No. 1, pp. 78-86. http://dx.doi.org/10.1086/383425

Cox, A. D., Cox, D., \& Zimet, G. (2006), "Understanding consumer responses to product risk information", Journal of Marketing, 70, January, 79-91. http://dx.doi.org/10.1509/jmkg.2006.70.1.79

Cox, A. D., Cox, D., \&Mantel, S. P. (2010), "Consumer response to drug risk information: The role of positive affect”, Journal of Marketing, 74, July, 31-44. http://dx.doi.org/10.1509/jmkg.74.4.31 
Danneels, E., Kleinschmidt,E.J. (2001), "Product innovativeness from the firm's perspective: its dimensions and their relation with Project selection and performance", Journal of Product Innovation Management, 18,357-373. http://dx.doi.org/10.1016/S0737-6782(01)00109-6

Foo, M. D. (2011). Emotions and entrepreneurial opportunity evaluation. Entrepreneurship: Theory \& Practice, 35, March, 375-393. http://dx.doi.org/10.1111/j.1540-6520.2009.00357.x

Forsythe, S.M. and Shi, B. (2003), "Consumer patronage and risk perception in internet shopping", Journal of Business Research, Vol. 56 No. 11, pp. 867-75. http://dx.doi.org/10.1016/S01482963(01)00273-9

Garcia,R.,Calantone,R.(2002), "A critical look at technological innovation typology and innovativeness terminology: a literature review", Journal of Product Innovation Management, 19, 110-132. http://dx.doi.org/10.1016/S0737-6782(01)00132-1

Gima K. A. (1995), "An exploratory analysis of the impact of market orientation on new product performance: a contingency approach", Journal of Product Innovation Management.12, 275293. http://dx.doi.org/10.1016/0737-6782(95)00027-Q

Goldsmith, R.E. and Hofacker, C.F. (1991), "Measuring consumer innovativeness", Journal of Academy of Marketing Science, Vol. 19 No. 3, pp. 209-21. http://dx.doi.org/10.1007/BF02726497

Goldstein, D. G., Johnson, E. J.,\&Sharpe, W. F. (2008). Choosing outcomes versus choosing products: Consumer-focused retirement investment advice, Journal of Consumer Research, 35(3), 440456. http://dx.doi.org/10.1086/589562

Hirunyawipada Tanawat and Paswan Audhesh K., "Consumer innovativeness and perceived risk", Journal of Consumer Marketing, Volume 23 - Number 4, 2006 , 182-198 (183)

Klerck, D., \& Sweeney, J. C. (2007). The effect of knowledge types on consumer-perceived risk and adoption of genetically modified foods. Psychology \& Marketing, 24, February, 171-193. http://dx.doi.org/10.1002/mar.20157

Kim, J.,Paek,H.J.(2009), "Information processing of genetically modified food messages under different motives: An adaptation of the multiple motiveheuristic- systematic model", RiskAnalysis, 29,1793-1806. http://dx.doi.org/10.1111/j.1539-6924.2009.01324.x

Klerck, D., \& Sweeney, J. C. (2007), "The effect of knowledge types on consumer-perceived risk and adoption of genetically modified foods", Psychology \& Marketing, 24, February, 171-193. http://dx.doi.org/10.1002/mar.20157

Knight, A. (2007), "Intervening effects of knowledge, morality, trust, and benefits on support for animal and plant biotechnology applications", Risk Analysis, 27, 1553-1563. http://dx.doi.org/10.1111/j.1539-6924.2007.00988.x 
Kuhlthau, C.C. (1991), "Inside the search process: information seeking from the user's perspective", Journal of the American Society for Information Science and Technology, Vol. 42 No. 5, pp. 361-371. http://dx.doi.org/10.1002/(SICI)1097-4571(199106)42:5<361::AID-ASI6>3.0.CO;2-\#

Kuttschreuter, M. (2006), "Psychological determinants of reactions to food risk messages", Risk Analysis, 26, 1045-1057. http://dx.doi.org/10.1111/j.1539-6924.2006.00799.x

Leavitt, C. and Walton, J. (1975), "Development of a scale for innovativeness", Advances in Consumer Research, Vol. 2, No. 1, pp. 545-55.

Lindell, M.K.,Hwang,S.N. (2008), "Households' perceived personal risk and responses in a multihazard environment", RiskAnalysis, 28, 539-556. http://dx.doi.org/10.1111/j.15396924.2008.01032.x

Lindell MK, Perry RW. (2012), "The protective action decision model: theoretical modifications and additional evidence". Risk Analysis, April, 32(4), 616-32. http://dx.doi.org/10.1111/j.15396924.2011.01647.x

Lowe Ben, Alpert Frank (2015), "Forecasting Consumer Perception of Innovativeness", Technovation, 45-46, 1-14. http://dx.doi.org/10.1016/j.technovation.2015.02.001

Midgley, D.F. and Dowling, G.R. (1978), "Innovativeness: the concept and its measurement", Journal of Consumer Research, Vol. 4 No. 4, pp. 229-42. http://dx.doi.org/10.1086/208701

Midgley, D.F. and Dowling, G.R. (1993), "A longitudinal study of product form innovation: the interaction between predispositions and social messages", Journal of Consumer Research, Vol. 19 No. 4, pp. 611-25. http://dx.doi.org/10.1086/209326

Moorman C. (1995), "Organizational market information processes: cultural antecedents and new product outcomes", Journal of Marketing Research, 32, 318-335. http://dx.doi.org/10.2307/3151984

Moorman, C.,Miner,A.S. (1997), "The impact of organizational memory on new product performance and creativity", Journal of Marketing Research, 34,91-106. http://dx.doi.org/10.2307/3152067

Ostlund, L.E. (1972), "A study of innovativeness overlap", Journal of Marketing Research, Vol. 9 No. 3, pp. 341-3. http://dx.doi.org/10.2307/3149552

Olshavsky,R.W.,Spreng,R.A.(1996), "An exploratory study of the innovation evaluation process", Journal of Product Innovation Management, 13,512-529. http://dx.doi.org/10.1016/S07376782(96)00037-9

Pearson, P.H. (1970), "Relationships between global and specified measures of novelty seeking", Journal of Consulting and Clinical Psychology, Vol. 34, pp. 199-204. http://dx.doi.org/10.1037/h0029010

Phillips Diane M., Hallman William K. (2013), "Consumer Risk Perceptions and Marketing Strategy: The Case of Genetically Modified Food", Psychology and Marketing, Vol. 30(9): September ,739-748. http://dx.doi.org/10.1002/mar.20642 
Robson Andrew, Robinson Lyn , (2015),"The Information Seeking and Communication Model", Journal of Documentation, Vol. 71 Iss 5 pp. $1043-1069$

Roehrich, G. (2004), "Consumer innovativeness: concepts and measurements", Journal of Business Research, Vol. 57, No. 6, pp. 671-7. http://dx.doi.org/10.1016/S0148-2963(02)00311-9

Rogers, E.M. (2003), Diffusion of Innovations, The Free Press, New York, NY.

Schiffmann Leon G. , Kanuk Leslie Lazar (2010), Consumer Behavior, Tenth Edition, Prentice Hall

Simcock, Peter , Sudbury, Lynn and Wright, Gillian (2006), "Age, Perceived Risk and Satisfaction in Consumer Decision Making: A Review and Extension", Journal of Marketing Management, 22. pp. 355-378. http://dx.doi.org/10.1362/026725706776861163

Slovic, P.,Fischhoff, B., Lichtenstein, S. (2001), "Facts and fears: understanding perceived risk", In:Slovic,P.(Ed.), The Perception of Risk, Earthscan,London, pp. 137-153.

Terpstra,T.,Lindell,M.K.(2013)," Citizens' perceptions of flood hazard adjustments: an application of the protective action decision model", Environ.Behav.45, 993-1018. http://dx.doi.org/10.1177/0013916512452427

Wood, S.L. and Swait, J. (2002), "Psychological indicators of innovation adoption: cross-classification based on need for cognition and need for change", Journal of Consumer Psychology, Vol. 12 No. 1, pp. 1-13. http://dx.doi.org/10.1207/S15327663JCP1201_01

Zepeda, L., Douthitt, R., \& You, S.Y. (2003), "Consumer risk perceptions toward agricultural biotechnology, selfprotection, and food demand: The case of milk in the United States", Risk Analysis, 23, 973-984. http://dx.doi.org/10.1111/1539-6924.00374

Zhu Weiwei, Wei Jiuchang, Zhao Dingtao (2016), "Anti-nuclear behavioral intentions: The role of perceived knowledge, information processing, and risk perception", Energy Policy, 88, 168 -177. http://dx.doi.org/10.1016/j.enpol.2015.10.009 